\title{
The Complexity of US-China Relationship: Examination Through Their Cooperation on Climate Change
}

\author{
Ziyi $\mathrm{Lu}^{1, *},{ }^{*}$, Zijing $\mathrm{Zhu}^{2, \dagger}$ \\ ${ }^{1}$ Lushan Bingjiang Experimental School, Changsha, Hunan, 410000, China \\ ${ }^{2}$ School of English, Xi'an International Studies University, Xi'an, Shanxi, 710000, China \\ *Corresponding author email: guanghua.ren@gecacademy.cn \\ These authors contributed equally.
}

\begin{abstract}
Climate change has become one of the most important threats for the world, which is the common challenge for US and China. Although some scholars are optimistic about the cooperation on climate changes between U.S. and China, factors that could greatly affect this process of cooperation to a large extent also exist, including competition for the global status, the argument of responsibilities undertaken by two difference kind of country with different development degree and even the alternation of regime, which cause the cooperation between the two countries extremely unstable. In the article, we will analyze the instability from the aspects of US-China competition for global leadership, mismatched expectation of responsibilities of carbon reduction, contentions over political disputes and also the fickle US domestic politics.
\end{abstract}

Keywords: Climate change, US-China relationship, international cooperation

\section{INTRODUCTION}

US and China are the two biggest carbon emitters in the world. They are obliged to lead together in adverting climate change and their collaboration is of vital importance. There are many scholars who believe that the future of US-China cooperation addressing climate change is hopeful and that it may even become the starting point for the two powers to cooperate in other fields. In Jiasi Jiang's research she believes there will be a win-win situation in the climate change collaboration and climate change can provide two nations an unprecedented opportunity of cooperation [1]. What's more, according to Xin Gao's essay he thought we had enough reasons to believe that cooperation in the area of global climate governance can have a positive effect on bilateral relations [2]. Many scholars hold optimistic opinions of US-China cooperation, but we suggest a more critical and cautious point of view be taken to analyze the issue, which is to understand the instability and complexity of their relations and take their political and economic conflicts into consideration.

The article is organized in the following way. Firstly, it provides a background of positive signals of cooperation between US and China and some scholars' prospects of positive collaboration between the two countries. Secondly, it addresses the instability of the cooperation between US and China concerning the climate change. In this part the article will discuss instability caused by competition for global leadership between US and China, their mismatched expectation of responsibilities of carbon reduction, their contentions over political disputes and fickle domestic politics in US.

\section{US-CHINA COOPERATION IN CLIMATE CHANGE}

Despite their increasingly cutthroat rivalry, this year the meeting in mid-April between John Kerry, U.S. Special Presidential Envoy for Climate and Zhenhua Xie, China Special Envoy for Climate Change sent a positive signal on climate change cooperation. At the conclusion of the discussion, these two Envoys issued the joint statement addressing the climate crisis. In this statement two states are committed to collaborating not only with each other but also with other nations to tackle the climate threats, advancing their relevant policies and 
collaborating in multilateral processes, for example, through the United Nations Framework Convention on Climate Change and Paris Agreement. The United States and China will also take the following actions in short term to further global climate governance. Firstly, both the United States and China are expected to work together in the 2021 United Nations Climate Change Conference (known as COP 26) in Glasgow which is aimed at promoting net zero carbon neutrality and accelerating the implementation arrangements for Paris Agreement. Secondly, both countries intend to support the developing countries' transformation from fossil fuel based energy to green and renewable energy by taking appropriate financial policies. Finally, they will conduct the alleviation of hydrofluorocarbon production and consumption which is reflected in the Kigali Amendment to the Montreal Protocol [3]. In addition to the joint statement, according to the special councillor of China Ministry of Ecology and Environment, Zhenhua Xie, since the COVID-19 and climate change are two severest crisis and require the biggest developed country and the biggest developing country to work together, US and China will join hands and strengthen cooperation to shoulder the responsibility of protecting the human race. Zhenhua Xie also argued that he has communicated with scholars from several US institutes and has joined international conferences addressing climate change during the pandemic and he believed the international society are highly concerned with the cooperation between US and China [4].

Based on the positive signals of cooperation between US and China discussed above, many scholars become optimistic about Sino-US relationship, and believe in a promising trend of US-China cooperation in the issue of climate change. For example, Aimee Barnes, Doctor Fan Dai and Angela Luh said that with a new presidential administration set in 2021, there is an opportunity for the two countries to build trust and cooperation on climate change which supports a cooperative and dynamic bilateral relationship. They expressed their anticipation for Biden government to collaborate with China actively to fight climate change and viewed it as a chance for US and China to restore their relationship [5].

The positive signals may suggest a bright future for the cooperation between U.S. and China, however, we need to look into the relationship between these two countries more cautiously, take various factors into consideration and understand that their cooperation is and will continue to be unstable.

\section{THE INSTABILITY OF US-CHINA COOPERATION ON CLIMATE CHANGE}

\subsection{Instability caused by competition for Global Leadership}

Nowadays, the influence of climate change has been more and more notable, since U.S. is the number one carbon emitter per capital, China has the largest carbon emission annually and both of them have great influence on the world, what they will do to tackle has received a widespread attention. Not only two governments but also international community hope they can reach a consensus on this global and momentous affair. However, it can be foreseen that the way to the collaboration is tough and filled with competitions because both of them want to boost their international status and be the front runner. The first kind of competition is in the international status, including the international right of speech and the dominant position of the climate global governance. As for Biden government, internationally, they argue, the United States can remodel their global leadership by strengthening the cooperation on climate change and multilateral cooperation, whereas in Opinions on Comprehensively Strengthening Ecological and Environmental Protection and Resolutely Fighting the Battle against Pollution issued by the CPC Central Committee and The State Council of China, it indicates that though the landmark Paris Agreement is the result of international community's agreement, the lack of global leadership and the divided posture of climate negotiating bloc lead to a rough process. Facing the new situation of international climate governance, China can play an active role in the field of climate change, further enhance the right of speaking in global climate governance and play a constructive role as a responsible power [6]. As both of them have nearly the same goal-improving their influence and playing a leading role in global ecological civilization construction, competitions exist and geopolitics can play a role.

Some other competitions are from the field of economy and mainly in green and renew energy industry, which is of great importance to implement the related policies in Paris Agreement. If the United State and China can have some collaboration in these field, it can be a win-win situation. However, looking back to the history, trade protectionism also spread to the area of clean energy. In November 2011, America launched a "double countervailing" investigation against China photovoltaic cells, imposing high anti-dumping and countervailing tariffs, making it difficult for relevant companies to enter the US market. Two years later, this investigation was carried out once again and the range of products involved was further expanded. Absolutely, this policy not only damages the trade cooperation between two nations, but also seriously undermines the cooperative effectiveness of China and the United States to deal with global climate change [7]. On top of that, the trade of environmental product based on climate change and the technology making use of new energy are the part of competition as well. This is because the climate crisis, in other words, can be the energy issue which is even at the core of climate change threat. In the age of climate change, energy supply is no longer guaranteed by military force 
to obtain the overseas oil suppy simply, the most important is to ensure the supply of clean and green energy [8].

\subsection{Instability caused by mismatched expectation of responsibilities of carbon reduction}

The conflict of climate change between U.S. and China is also embodied in their divergent attitudes towards the extent developed countries and developing countries should shoulder their respective responsibilities in climate governance. Actually in 1997, at the time when Kyoto Protocol was ratified, this question had a basic answer-The Principle of Common but Differentiated Responsibility, which claims that it is both developed and developing countries' common duties to protect environment, developed countries need to have great contributions on climate governance, not only setting a stringent goal but also helping developing countries to reach the targets. It seems that the Principle of Common but Differentiated Responsibility sets out a foundation for cooperation between developing and developed countries, but why there still are conflicts between these two? It is because this principle can't be implemented successfully in reality. Developed countries always shirk their responsibilities for sundry reasons and the goal of emission reduction is far from the requirement of IPCC (Intergovernmental Panel on Climate Change)'s report. US is such an example that it escapes its own carbon reduction responsibility and puts pressure on China to make impractical actions to shoulder responsibilities beyond its fair share. And in China's opinion, developing countries are still quite behind developing countries and that to ask emerging economies to assume the same international responsibilities as developed economies is not fair and that it is beyond the capacity of emerging economies according to the Vice-Minister of Foreign Affairs Tao Song [9]. And as for emission intensity standard, China adopts the standard that is based on its large population, while the U.S. urges China to adopt the total emission standard. All in all, if the two states really want to tackle climate crisis together, it's not a good idea to blame each other, but cooperate sincerely and try their best to reduce the carbon emissions.

\subsection{Instability caused by contentions over political disputes}

Even though U.S. and China have reached a consensus on some parts of global climate governance, it doesn't mean their relationship on other field can be established definitely. Two governments may be trying to prevent their relationship from further deteriorating by using the collaboration on climate crisis, but their unswerving and antithetical postures on some hot issues make them hard to resolve contradictions on some affairs, which may affect US-China relation. While China regards Tibet, Xinjiang, Hong Kong and Taiwan as internal affairs, the United States has passed relevant bills in the parliament, infuriating the Chinese government. The riot in Hong Kong in 2019 is an archetypical example. In November 27th of last year, Hong Kong Human Rights and Democracy Act was ratified by American parliament, which, in China's perspective, was to indicate the support of anti-China forces in Hong Kong and deteriorate the violence there. In addition to this in July 14th 2020, Hong Kong Autonomy Act was signed by Trump, which called for sanctions against foreign individuals or entities alleged to be involved in China's breach of Hong Kongrelated obligations, as well as foreign financial institutions engaged in significant transactions with the individuals or entities concerned, and supports the entry of "being persecuted" Hong Kong residents into the United States. In response to this bill, the Chinese Foreign Ministry emphasizes, U.S. has no rights to interfere Chinese internal affairs. According to Chinese Foreign Minister, Wang Yi, implied that whether there is cooperation between China and U.S. depends on if U.S. interfere Chinese internal affairs, which has an implicit meaning that the political factor can have an influence on the cooperation between U.S. and China, however, John Kerry, U.S. Special Presidential Envoy for Climate, has made it clear that the U.S. will not make a concession on these matters for climate changes [10]. So, based on this, it can demonstrate that unless one of these countries softens its position, tensions between China and the United States over some hot-butter issues can be expected to threaten bilateral climate efforts.

The tension between China and U.S. has harden, and some scholars and political elites from both countries speculate that their relationship is entering a period called "New Cold War". Although it is widely agreed that the new phase is apparently different from the Cold War after World War II since that China and the U.S. are economically and socially dependent on each other and that the world now is not divided into two camps as it was during the Cold War, the history of the Cold War and the different ideologies of the two countries still have a strong impact on their relationship. According to Minghao Zhao's article "Is a New Cold War inevitable?", Chinese scholars have been debating about the deterioration of US-China relationship since the implementation of the U.S. "Pivot to China" policy in 2011-2012, and discussions on US-China strategic competition have become even more heated when the Trump administration have shifted their major policy against China [9]. The impact of divergence of ideologies has become more evident in recent years and the ideological competition between the two countries have entered a new phase, which Dalei Jie from Peking University called "defensive ideological competition" [11]. In the new phase the U.S. is more aware of China's challenge and more actively competes with China. The National Security Strategy Report of Trump 
administration pointed out that the United States had entered a new period of major power competition and that China had become its "strategic competitor". The shift of the U.S.'s attitude towards China is shown in its policies in various fields. The trade war launched by the U.S. is an example in economy, while there is also military friction in the South China Sea and more conflicts over the Taiwan issue. After Trump, Biden's administration also considers China to be a powerful competitor and is cautious with its collaboration with China. The competition on multiple fronts is inevitable for the two superpowers not only because of their disagreements in ideologies, but also because of the radical change in international order. In conclusion, the future cooperation of the U.S. and China will be unstable due to political contentions and that there will be more unavoidable challenges.

\subsection{Instability caused by fickle US domestic politics}

The U.S.'s willingness to cooperate is often effected by its domestic political changes, which can be very unstable. The separation of three powers is one of the most important features of the United States' politics and different groups and various stakeholders also play important roles in politics, which have determined the complexity of its legislation process. The Democratic Party tends to be more active when facing climate change while the Republican Party is comparatively more passive. For instance, as a Democrat, Barak Obama is an active promoter of actions addressing climate change. Domestically, he launched the "The Recovery Act" that encouraged the search for clean energy and technological innovation, and also promoted the reduction of carbon footprint and the establishment of climate change mechanism. Internationally, the Obama government enhanced cooperation with the international society on climate change, and it hosted the Major Economies Forum on Energy and Climate. And as a republican, Donald Trump was relatively much more passive on issues concerning climate change and even Trump government withdrew from the Paris Agreement. The reason for the different attitudes is that the two parties speak for different interest groups and it is difficult for them to reach a consensus, especially on vital issues like the climate change. The split of the two parties' policies often causes the complete distinctions in climate policies in different periods and makes it difficult for a certain climate policy to last for a long time. Therefore, longterm goals in adverting climate change seem unlikely to be fulfilled and cooperation with countries like China seem even harder to maintain, which contributes to the instability of the two countries' cooperation.

\section{CONCLUSION}

The United States and China are obliged to lead together and set an example of cooperation in climate change for all the other countries. However, we believe scholars should be encouraged to provide different views. Instead of being blindly optimistic, we should be perfectly aware of all the challenges and obstacles and take all factors into consideration. We believe the article provides an important perspective to look into the instability of US-China cooperation and analyze why the instability exists and how to stabilize the cooperation between the two countries. We believe it is necessary to make efforts to stabilize their cooperation. The two countries should restore mutual trust by enhancing both governmental and non-governmental communication and collaboration, while also openly discussing political and economical issues that hinder their cooperation. It is crucial for the two governments to realize the urgency of joining hands for common interests concerning climate change, for it affects not only the two countries, but also all other countries in the world. Climate issues should never be over politicized for it has the power to determine the future of the whole human race, and therefore the cooperation of the United States and China in this area is of vital importance. The article aims at stressing the problems in their cooperation and hopes to act as a reminder to scholars in this field to do further research on improving US-China cooperation on climate change.

\section{REFERENCES}

[1] Jiasi Jiang, US-China Climate Change Cooperation: create win-win situation from financial crisis, Green Leaf,03,2009:86

[2] Xin Gao, China-U.S. Climate Change Cooperation and Its Impact,April 10,2017

[3] American Office of The Spokesperson , U.S.-China Joint Statement Addressing the Crisis, https://www.state.gov/u-s-china-joint-statementaddressing-the-climate-crisis/

[4] Zhenhua Xie, China and the U.S. Should restart cooperation in Climate Change and Turn From Competing to Achieving Mutual Benefit,Globalization 2,2021

[5] Aimee Barnes, Dr.Fan Dai and Angela Luh, HOW THE UA AND CHINA COULD RENEW COOPERATION ON CLIMATE CHANGE, https://www.energypolicy.columbia.edu/sites/defau lt/files/file-

uploads/Biden_China_CGEP_Commentary_v3.pdf

[6] Tianjin Daily, Leading the Construction of International Ecological Civilization and Contribute to Global Climate governance,http:/www.ce.cn/cysc/newmain/yc/jsx w/201807/30/t20180730_29888777.shtml

[7] Bing Zhao and Shuming Xie, Return Paris 
Agreement : new changes in Biden administration, Peace and Development,03,2021

[8] Jenny Wan, Strategic Games among Sino-US-EU in International Climate Political Pattern,June,2011

[9] Tao Song, Munich Security Conference,02,2013

[10] Minxin pei, The Limits to US-China Climate Change Cooperation, Project Syndicate, 05,2021

[11] Dalei Jie, Ideologies and Sino-U.S. Strategic Competition, Quarterly Journal of International Politics

[12] White House, The Recovery Act, https://obamawhitehouse.archives.gov/the-pressoffice/2016/02/25/fact-sheet-recovery-act-madelargest-single-investment-clean-energy 